ISSN = 1980-993X - doi:10.4136/1980-993X
www.ambi-agua.net
E-mail: ambi-agua@agro.unitau.br
Tel.: (12) 3625-4212

\title{
Water table monitoring in a mined riparian zone
}

(doi:10.4136/ambi-agua.117)

\author{
Thomaz Marques Cordeiro Andrade ${ }^{1}$; Herly Carlos Teixeira Dias ${ }^{2}$ \\ ${ }^{1}$ Technische Universität Dresden (TUD) - Germany \\ E-mail: thomazuai@yahoo.com.br \\ ${ }^{2}$ Universidade Federal de Viçosa (UFV) - Brazil \\ E-mail: herly@ufv.br
}

\begin{abstract}
The objective of this study was to test an easily fabricated tool that assist in the manual installation of piezometers, as well as water table monitor in the research site, located at the Gualaxo do Norte River Watershed, state of Minas Gerais, Brazil. The tool is made of iron pipes and is a low-cost alternative for shallow groundwater observation wells. The measurements were done in a riparian zone after being gold mined, when vegetation and upper soil layers were removed. The wells were installed in three areas following a transect from the river bank. The method was viable for digging up to its maximum depth of 3 meters in a low resistance soil and can be improved to achieve a better resistance over impact and its maximum depth of perforation. Water table levels varied distinctly according to its depth in each point. It varies most in the more shallow wells in different areas, while it was more stable in the deeper ones. The water table profile reflected the probably profile $f$ the terrain and can be a reference for its leveling in reconstitution of degraded banks where upper layers of the soil were removed. Groundwater monitoring can be also an indicator of the suitability of the substrate for soil reconstitution in terms of the maintenance of an infiltration capacity similar to the original material.
\end{abstract}

Keywords: Piezometer; Groundwater; Degraded land; Water table; monitoring.

\section{Monitoramento do nível de água do aquífero freático de uma área ripária minerada}

\section{RESUMO}

O objetivo do presente trabalho é testar um equipamento para a perfuração manual de piezômetros rasos e fazer o monitoramento do nível d'água do aqüífero freático na bacia do rio Gualaxo do Norte, em Mariana, MG. A ferramenta é composta de tubos metálicos e pode ser uma opção de baixo custo para a perfuração de piezômetros rasos. As medições foram feitas em uma zona ripária após a extração de ouro por draga, que removeu a vegetação e alterou as camadas superiores do solo. Os poços foram perfurados em três áreas distintas, divididas em três parcelas seguindo um transecto perpendicular à margem do rio. A ferramenta se mostrou eficiente para a perfuração de poços de até 3 metros em solos de baixa resistência, e poderá ser aprimorada para aumentar sua resistência ao impacto e sua profundidade de perfuração. O nível do lençol freático sofreu variações diferentes de acordo com a sua profundidade em cada ponto, os poços mais rasos variaram de forma semelhante em diferentes áreas, e os mais profundos se mostraram mais estáveis. $\mathrm{O}$ nível freático refletiu as prováveis características fisiográficas do terreno e pode ser uma referência para o nivelamento do mesmo na reconstituição de margens degradadas onde houve a retirada das camadas superiores do solo. O monitoramento do nível do aqüífero freático pode ser um indicador da adequação do substrato da recomposição do solo em áreas degradadas no que diz respeito à manutenção da capacidade de infiltração compatível com a do material original.

Palavras-chave: Piezômetro; aqüífero freático; área degradada; nível d'água; monitoramento. 


\section{INTRODUCTION}

One of the most common goals of scientific research and public efforts for the environment is to improve water quality. Many efforts have been made to find scientific basis to landscape management practices focusing on the improvement or at least maintenance of water quality and quantity for human consumption and to keep ecosystem stability. An example of that is that the watershed is being proposed to be the basic geographic unit for sustainable management programs.

The saturated subsurface zone, or phreatic zone, contains the largest source of unfrozen fresh water in the world. An understanding of the storage and movement of groundwater is necessary for appreciating other components of the hydrologic cycle. It plays an important role to integrate the other components of the cycle, as well as water storage and discharge (Dunne and Leopold, 1978).

Water-level measurements from observation wells are the principal source of information about the hydrologic stresses acting on aquifers and how these stresses affect ground-water recharge, storage, and discharge (Taylor and Alley, 2001). These wells measure the head, or piezometric potential, which are simply the elevation of the water table at any given point, and are also called piezometers.

A network of piezometers allows groundwater level monitoring through the variation of head. The wells are usually inserted by specialized machines, carried by trucks or tractors, for which high costs and the lack of accessibility to steep or saturated areas can be limiting factors.

This paper presents a test of an easily fabricated tool that assist in the manual installation of shallow ground water observation wells, which can be an alternative to the costly and sometimes inaccessible mechanical installation. The tested tool is especially useful for areas where the depth of the water table is low, what characterizes generally critical areas of a watershed's management in terms of sediment or nutrient transport control, also called Variable Source Areas (VSA).

Furthermore, it presents and analyzes groundwater level monitoring data in an area that has been degraded by intensively gold mining. The study also provides data for a larger research project that includes soil and forest cover restoration of the Gualaxo do Norte River watershed in the city of Mariana, Brazil.

\section{MATERIALS AND METHODS}

The research has taken place at the Gualaxo do Norte River watershed, which is part of the watershed of the Rio Doce River, one of the major rivers in East of Brazil. The research site is located in the northern part of Mariana County, state of Minas Gerais, near a Village called Monsenhor Horta; $20^{\circ} 14^{\prime} 18^{\prime}$ ' south of the Equator and $41^{\circ} 19^{\prime} 58^{\prime}$ ' west of Greenwich (Figure 1).

The watershed is formed by steep hills in its upper half, covered mostly with Tropical Semideciduous Forest and less steep areas in its lower part, where most of the land is occupied by small farms with crops and pasture. In spite of that, agriculture is not an expressive economical activity of the region, apart of the Eucalyptus plantations for charcoal production. As the area is rich in metallic and non-metallic minerals, iron and iron-manganese ore mining companies are the major source of development in the region. It is also rich in gold, but most of it was taken in the $18^{\text {th }}$ century. Notwithstanding, fine particles of gold remain in the bed of many rivers and are now being extracted by local people. The method consists basically in dragging sediment from the river bed using dredges and pumps and gold is obtained by decantation. 


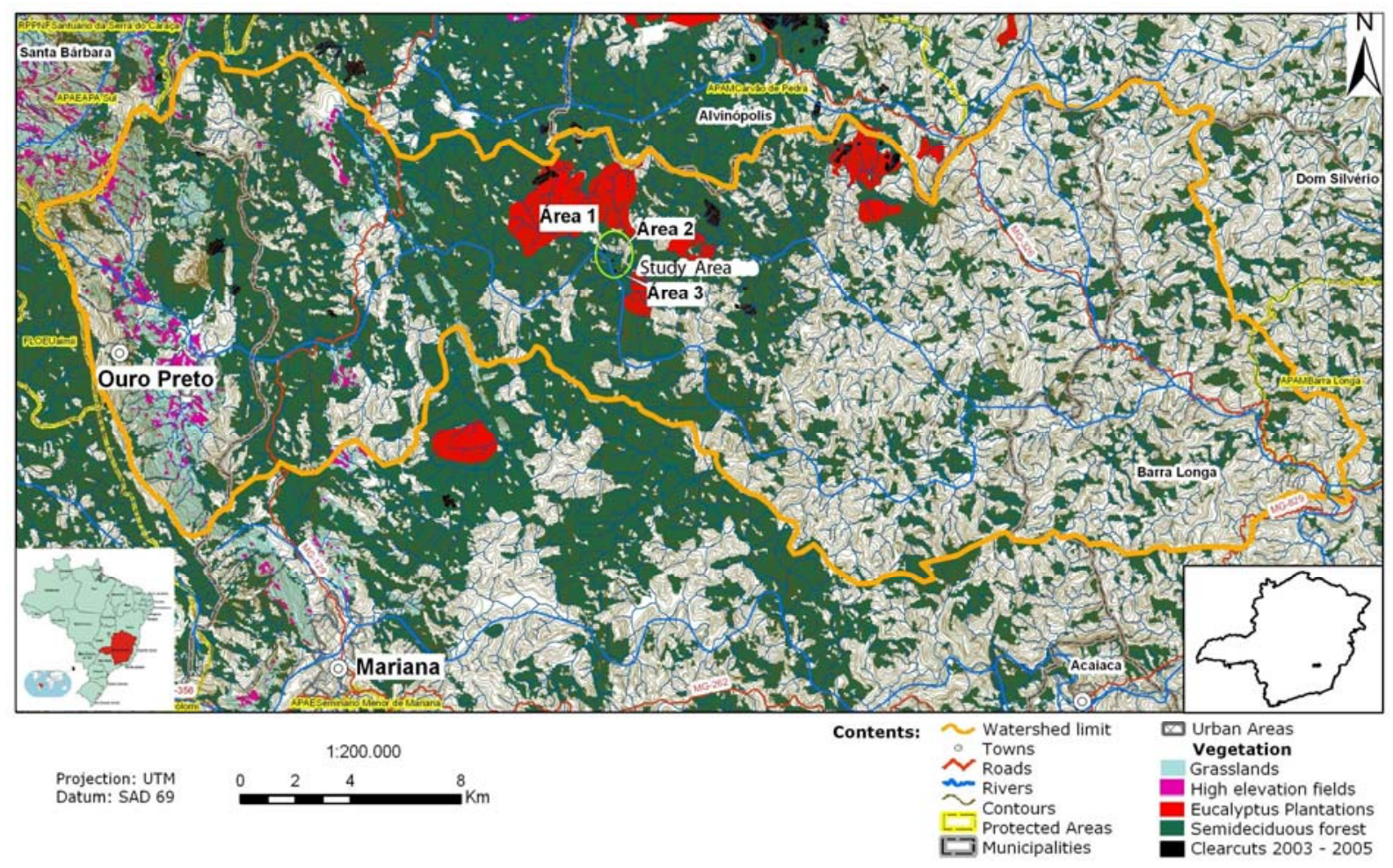

Figure 1. Map of the Gualaxo do Norte River Watershed, Minas Gerais, Brazil, 2007.

According to Ferreira et al. (2006), although dredge mining has a social importance for the local population, being a major source of income at nearby communities and hence social and economical sustainable, it causes considerable environmental impacts and does not maximize the utilization of the mineral resources.

The area has been dragged for about 8 years by local people, in an arrangement where the ownership of the pumps and dredges as well as the labor force comes from the local population. It was done in an unauthorized way, not following state regulations until 2004, when the miners founded a cooperative, through which they seek technical support from the Universities of Ouro Preto (UFOP) and Viçosa (UFV). Since then, few research projects have been done in the area (e. g. Ferreira et al., 2006), focusing on environmental diagnostics and restoration.

The present study was done while the area was still in an initial stage of restoration that was, however, performed by the miners themselves without specific technical criteria. It was just after this primary step that research projects start giving support from university's scholars and students.

Monitoring sites were distributed in three areas along the east bank of the river (Figure 2), where original top soil was relocated, with three different bank heights, which had referenced the depth of the installed wells (Table 1). Three piezometers were installed in each site, following a transect, with about 15 meters between each measure point. 


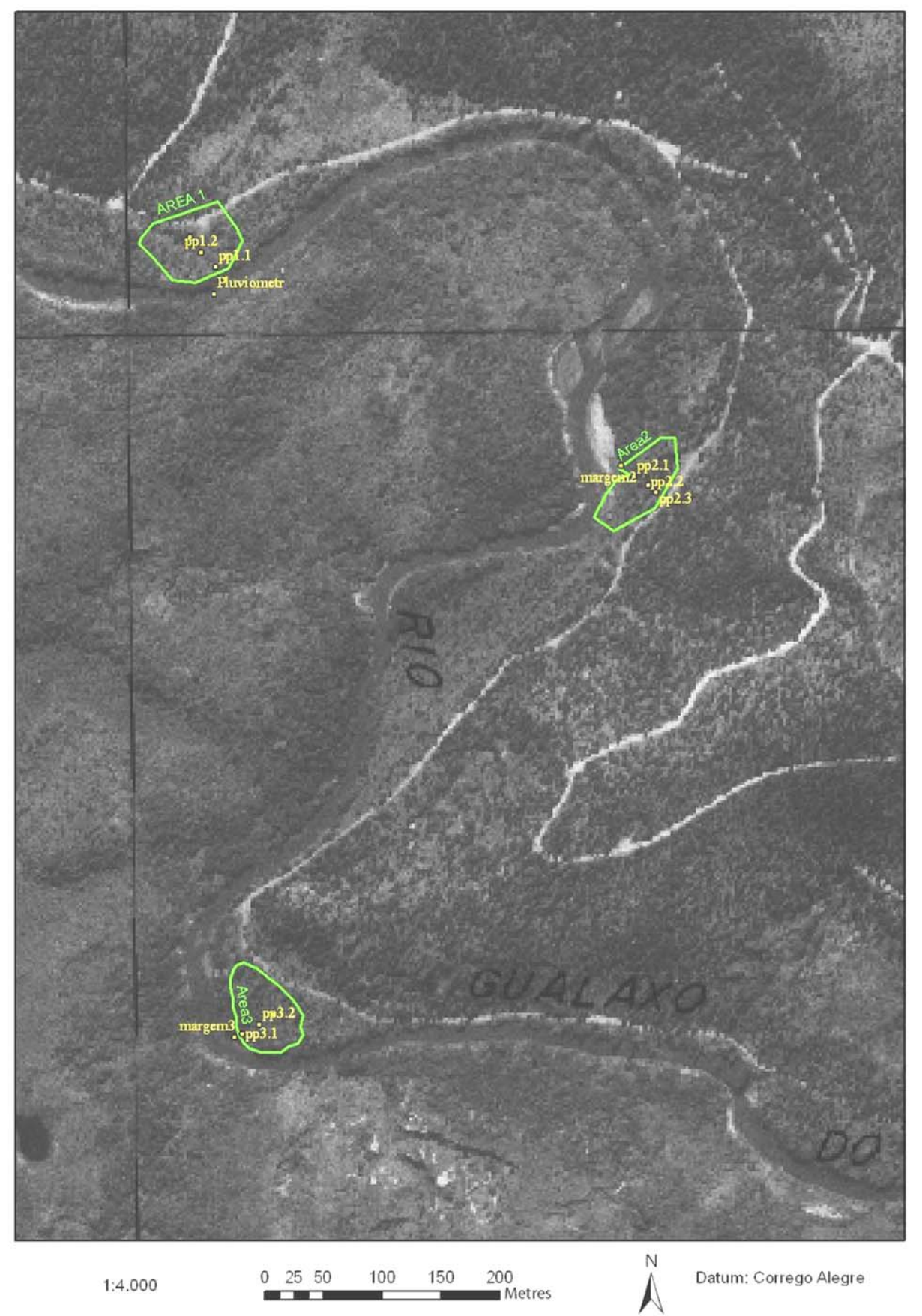

Figure 2. Distribution of Piezometers drilling areas.

Table 1. Bank heights, depth of the wells, in meters, and size of each plot, in hectares, installed at the Gualaxo do Norte River Watershed, Minas Gerais, Brazil, 2007.

\begin{tabular}{l|cccc}
\hline Area & Piezometers & Bank height (m) & Depth of the wells (m) & Plot size (ha) \\
\hline 1 & $1.1 ; 1.2 ; 1.3$ & 2 & 2.5 to 3 & 0.37 \\
2 & $2.1 ; 2.2 ; 2.3$ & 0 & 1.5 & 0.28 \\
3 & $3.1 ; 3.2 ; 3.3$ & 0.85 & 2 & 0.31 \\
\hline
\end{tabular}

The tool used to dig the wells was fabricated based in the one suggested by Bohn (2001). It has three components: an outer sleeve, an inner core, and a pounder (Figure 3). The coresleeve assembly is driven into the ground with a modified hand-held pounder. For wells deeper than 1.5 meters an additional metal pipe is used to dig the rest of the hole (Figure 4). Once the assembly has been driven its full length, the iron pipe is lifted out and replaced with 
PVC pipe for permanent well casing. The permanent pipe has several holes of about $1 / 4$ inch in the last $30 \mathrm{~cm}$, covered with a permeable screen to avoid clogging by soil particles without preventing the water movement into the well. The screen also covers the lower end of the pipe.

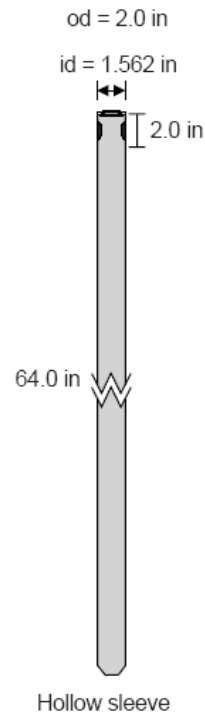

(a)

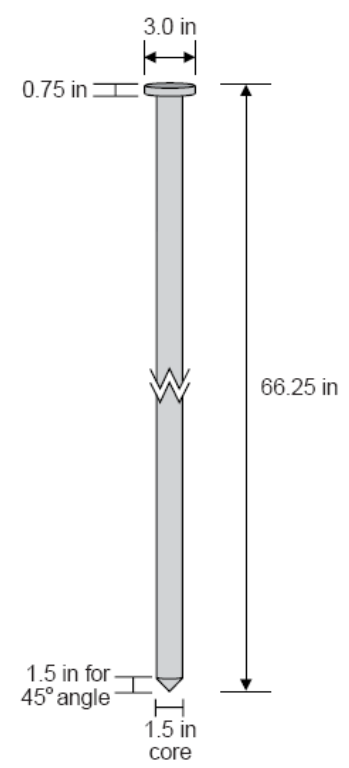

(b)

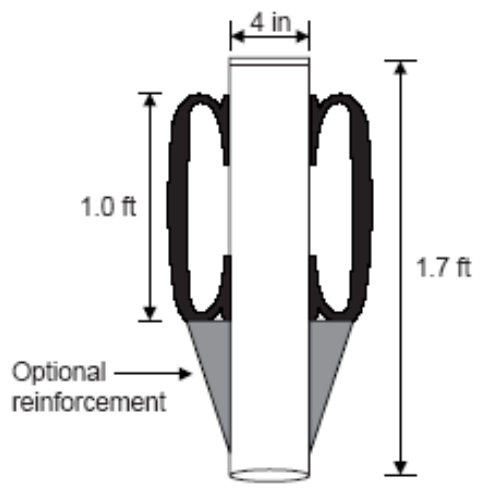

(c)

Figure 3. Components of the manual drilling tool: a) outer sleeve; b) inner core; c) pounder.

Source: Bohn (2001).

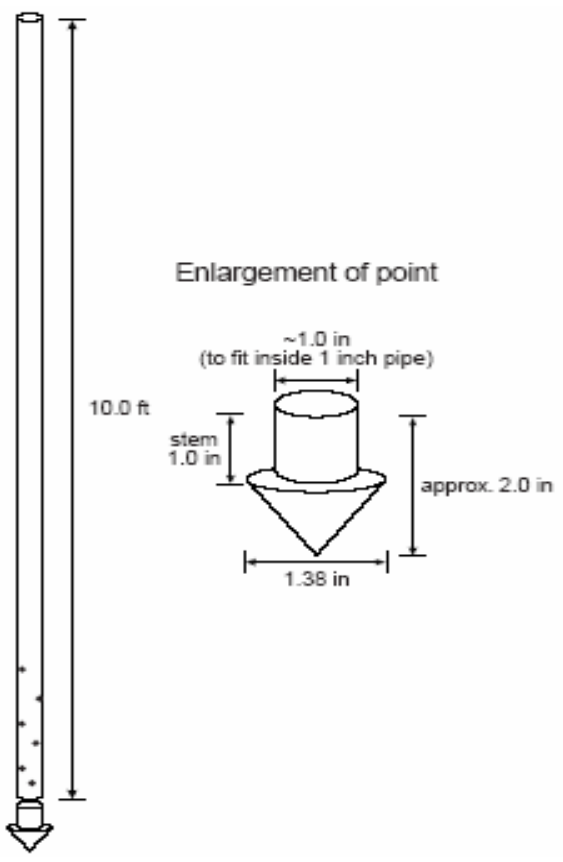

Figure 4. Complement pipe for well drilling up to 3 meters and steel point enlargement (out of scale).

Source: Bohn (2001). 
The depth of the free water surface in the well was measure by a water level meter Solinst ${ }^{\circledR}$, model 101, composed by a sensor and a scaled cable where the values are read. Data was collected from April $27^{\text {th }}$ to July $2^{\text {nd }} 2007$, with 6 measurements between uneven intervals within this period.

Aiming to have a better characterization of the soil, its mechanical resistance was assessed by a regular penetrometer, once beside each well, being the final value the average of five measurements around it, taken in the last day of data collection. In addition, we have opened a soil profile in two wells at site 1 to have a better view of the substrate horizons and compact layers and also possible effects of the well drilling on it.

\section{RESULTS AND DISCUSSION}

The manual well digging methodology was used successfully to perforate the piezometers at the three areas previously determined. Hence the presented methodology can be considered viable. Usually the first 0.5 to 1 meter of the well was easily punched and the soil resistance to perforation increase at deeper layers.

Although it was possible to dig the wells using this method, some flaws were detected in the equipment during the process, especially deformations in result of the impact transmitted by the pounder (Table 2). Most of the deformations were observed after the first wells were completely perforated, in the core and the sleeve. The 3 meters complement pipe has also shown some deformations, but smaller.

Table 2. Observed Flaws and recommendations for the improvement of the manual well drilling tool used at the Gualaxo do Norte River Watershed, Minas Gerais, Brazil, 2007.

\begin{tabular}{|c|c|c|}
\hline Component & Flaws & Recommendations \\
\hline Inner Core & $\begin{array}{l}\text { - Folds on the wall at the } \\
\text { upper end. }\end{array}$ & $\begin{array}{l}\text { - Use a solid iron bar of } 1 \text { or } 7 / 8 \text { inches diameter } \\
\text { - Increase the length to } 2 \text { meters }\end{array}$ \\
\hline Outer Sleeve & $\begin{array}{l}\text { - Folds on the upper end } \\
\text { and walls by pressure } \\
\text { from the core } \\
\text { deformations. } \\
\text { - Decrease of total length }\end{array}$ & $\begin{array}{l}\text { - Decrease the diameter to } 1 \frac{1 / 2}{2} \text { inch. } \\
\text { - Place reinforcements on the wall between the } \\
\text { removing holes } \\
\text { - Decrease the diameter of the removing holes. } \\
\text { - Increase the lenght to } 2 \text { meters. }\end{array}$ \\
\hline $\begin{array}{l}\text { Auxiliar pipe } \\
\text { ( } 3 \text { meters) }\end{array}$ & $\begin{array}{l}\text { - Deformations at he upper } \\
\text { end and removing holes }\end{array}$ & $\begin{array}{l}\text { - Substitute by a solid iron bar } \\
\text { - Decrease the diameter of the side holes } \\
\text { - Increase the length to } 4 \text { meters }\end{array}$ \\
\hline Pounder & - not found & - Increase the length to 80 centimeters \\
\hline $\begin{array}{l}\text { Permanent } \\
\text { cover (PVC) }\end{array}$ & $\begin{array}{l}\text { - Sediment entering } \\
\text { through the lower end }\end{array}$ & - Use of several layers of plastic screen \\
\hline
\end{tabular}

The first flaw observed was in the upper mouth of the sleeve, in which the metal got folded and projected outside, leading to a diminution of about $2 \mathrm{~cm}$ of the sleeve's length (Figure 5a). This decrease of length had made the core longer than the sleeve and therefore got projected out of the lower mouth of the cover (Figure 5b). The inner diameter of the lower edge of the external tube is slightly smaller than the core, so both pieces got locked to each other. The core was deformed about $2 \mathrm{~cm}$ from the upper edge, at the height of the holes used to remove it from the ground. At this point, the metal folds perpendicularly to the tube length, causing a pressure to the sleeve, what had also contributed for both to get locked (Figure $3 \mathrm{a}$ ).

The distortions in the 3 meters complement occurred also in the wall next to the removing holes (Figure 5c). Because of its smaller diameter, a reduced volume of soil is dislocated while punching what needs less strength to be done and hence less pressure on the tool. In addition to the larger volume of soil dislocated and pressure on the core-sleeve 
assembly, a higher friction was generated by the fact that the two pieces point did not form a continuous angle, what contributed in the end for major deformations.

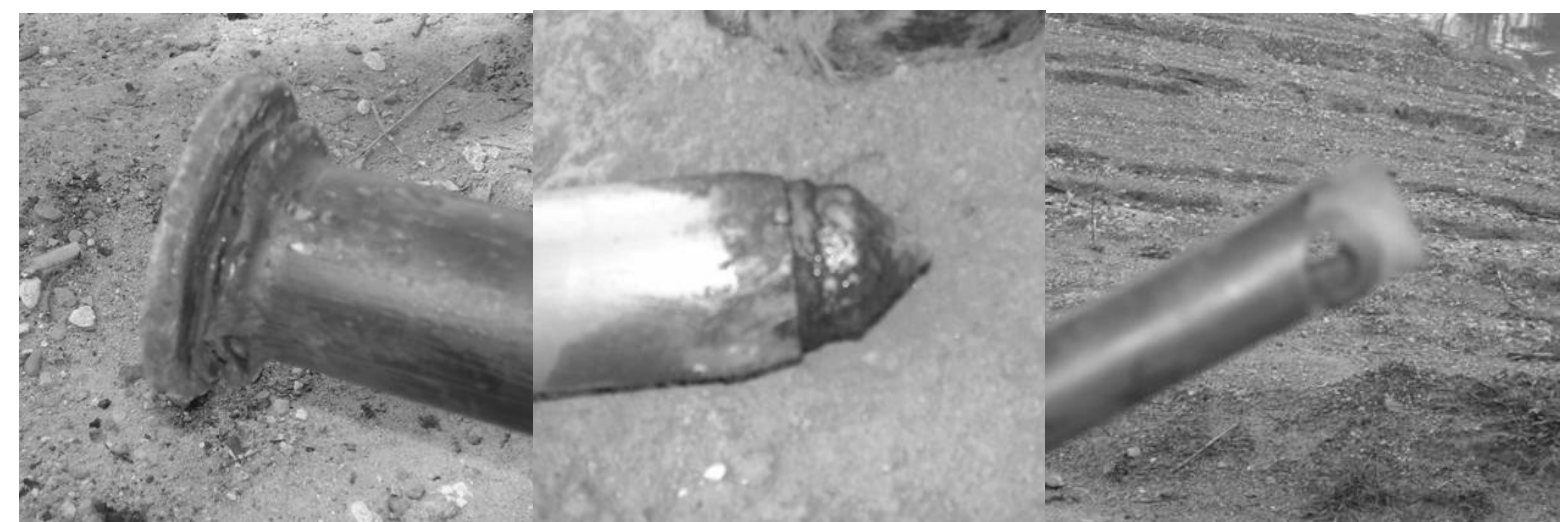

(a) (c)

Figure 5. Deformations observed in the manual drilling tool componts, used at the Gualaxo do Norte River Watershed, Minas Gerais, Brazil, 2007: a) Folds at the upper part of the core and sleeve; b) decrease of the sleeve length and consequent projection of the core; c) deformations at the wall between the side holes of the 3 meters complement.

The modifications needed to prevent the observed flaws and enhance the performance of the manual digging tool are summarized on Table 2. Steel pieces can be placed to reinforce the wall from between the removing holes to the upper end in the sleeve and in the 3 meters complement. To reinforce the core, the hollow tube can be replaced by a solid bar. In this case, the point can be made just by modeling the end of the bar, making it not necessary to solder another piece of metal, what can also increase its strength over impact. Another recommendation is to reduce the diameter of the sleeve and the core for $1 \frac{1 / 2}{2}$ and 1 or $7 / 8$ inches respectively, in order to decrease the friction by the volume of soil dislocated. A solid bar of the same diameter can be used for the 3 meters complement, associated with the diminution of the lateral orifices.

As well as the structural modifications to avoid flaws, the experiment has shown that it is possible to increase the maximum depth of the piezometers perforated by this tool by increasing the length of the pipes to 2 and 4 meters. In this new scenario, the procedure should be viable with a 30 centimeters increase in the length of the pounder.

Another flaw detected in the tested method was that in many cases sediment entered the permanent PVC cover from the bottom end during installation. In all the wells, the sediment level was lower than the water level for all dates of measurements. However, the sediment column in the bottom of the piezometers decreases the available depth of the piezometers and can eventually prevent future readings if the water level continues to drop. A simple form of solving this problem would be by placing a cork cover (or similar material) at the end of the pipe (Bohn, 2001). However, this option made the lateral holes the only way of groundwater to enter the well, that can be undesirable in some cases. A solution can be a cover well permeable to water but not much for soil particles, like a thicker plastic screen than that one used originally or placing several screen layers in the bottom of the well.

In the present study, the water table variations were considered as spatial (distance from the river bank) and temporal (over time; Figures 6 and 7). Although the water level is considered in negative numbers, having the ground level as a reference to bring an idea of the phreatic profile through the chart, errors might be associated with that because the piezometers were not leveled in each area.

Spatial variation (Figure 6) was different in each area. At area 1, the depth of water decreased with the increase of distance to the river for the whole period. In this area, the 
terrain was leveled after gold extraction without considering its original characteristics. Here groundwater profile can be an indicative of a tendency of the original ground topography. As the research site is located in a steep area, it is expected a downward sloping water. Marinho and Castro (2003) observed that in a hilly slope area, water table had shown a convex shape at most of the watershed, including areas near the river bank, where they have registered the lowest groundwater levels. This is one of the most common groundwater hydrologic model behavior (Dunne and Leopold, 1978) and the findings at area 1 indicates that water table is following this pattern.

The chart of areas 2 and 3 presents pattern quite different from area 1 (Figure 6). In both cases, the depth to the water was lower at the wells by the river (2.1 and 3.1), increasing at the center of the plot (2.2 and 3.2) and decreasing again in the backward wells (2.3 and 3.3). In both areas, water table was emerging to the ground on the back of the plot (near well 3). Also, the level difference between the wells was smaller at area 2 and 3 showing that in these areas, water table and consequently original ground surfaces are tending to be flat. The maximum difference between water levels ranged between 15 and 20 centimeters at area 2 and 3 while at area 1 it reached more than a meter.

Figure 7 illustrates the variation of head through time in each area. Temporal variation was similar in all three areas, except in the last measurement of area 3 . Overall, there was a rise of the water table in the beginning of May. In area 1, the magnitude of this elevation was higher at longer distances to the river, suggesting that it was a response of precipitation directly in the area where the piezometers are installed. After that the level was decreasing until June $15^{\text {th }}$, when a new rise was observed in some wells. At this time, the elevation was higher at well 1.1, the closest to the river and at all wells of area 2. These wells have water levels closer to the soil surface and hence are more susceptible to straight effects of variations in the river surface level, that can be a reflect of rainfall in a larger range of time and space in the whole upstream areas of the catchment. At area 2, water table rose between 11.3 and 17.7 $\mathrm{cm}$ from $5^{\text {th }}$ to $15^{\text {th }}$ of June. Variation at this area was similar to the well 1.1, where the water got $15.4 \mathrm{~cm}$ higher at the same period. As the ground at area 2 is at almost the same level of the river, all wells of the transect are subjected to a high influence of the river level. The well 1.1 got similar pattern, but not the other wells in area 1. Table 3 displays rainfall data in the research site between the last week of May and the first week of July. The period of measurements had less precipitation than expected. The low water table reinforces the evidences that most of the variations on groundwater levels is a result of events throughout the watershed highly influenced by surface water levels.

Table 3. Precipitation registered by a nonrecording rain gauge installed at the Gualaxo do Norte River Watershed, Minas Gerais, Brazil, 2007.

\begin{tabular}{c|c}
\hline date & precipitation $(\mathbf{m m})$ \\
\hline 28/May & 5.15 \\
4/Jun & 10.13 \\
2/Jul & 2.6 \\
\hline
\end{tabular}


ANDRADE, T. M. C.; DIAS, H. C. T. Water table monitoring in a mined riparian zone. Ambi-Agua, Taubaté, v. 5, n. 1, p. 29-42, 2010. (doi:10.4136/ambi-agua.117)
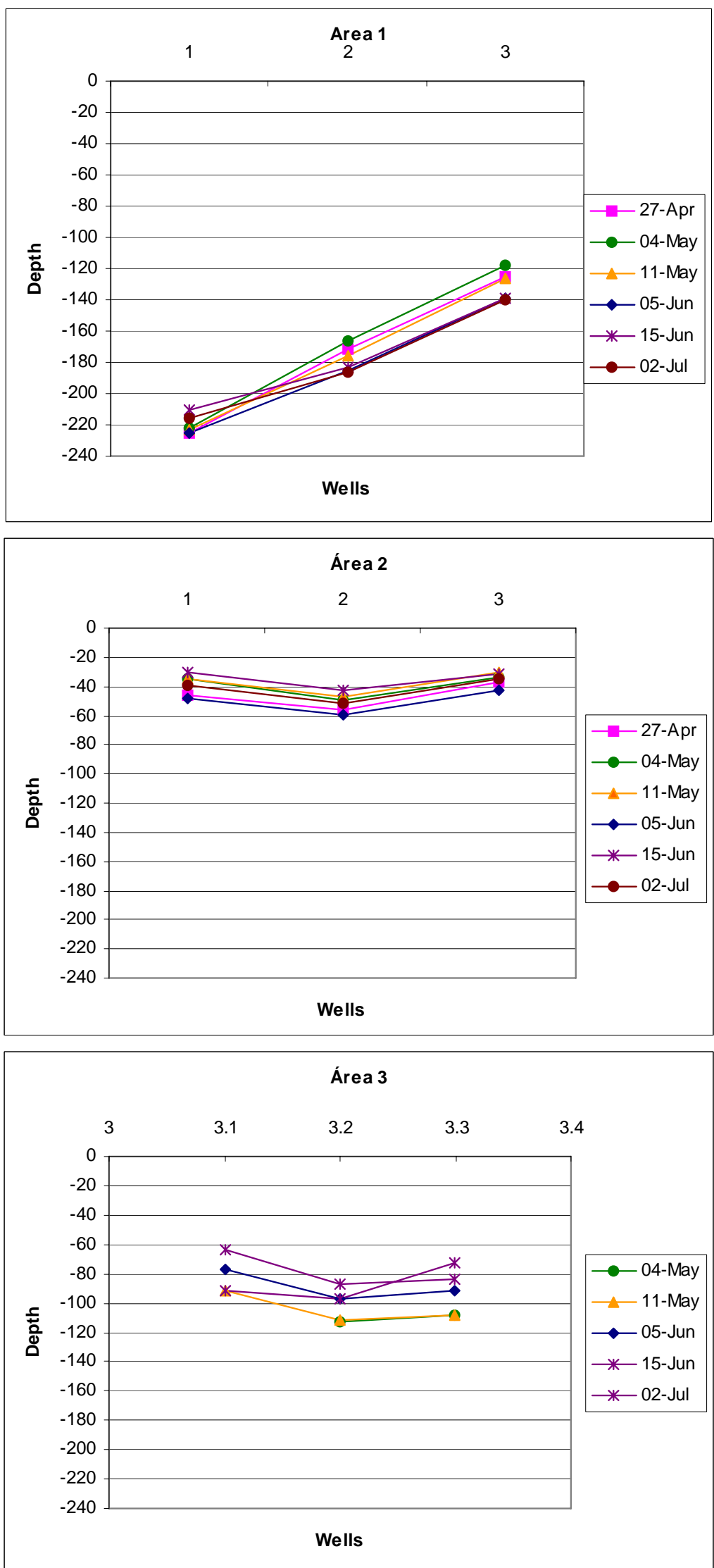

Figure 6. Spatial variation of groundwater level in the three observed areas, in centimeters, following a transect from the Gualaxo do Norte River bank. Minas Gerais, Brazil, Apr/Jul, 2007. 
ANDRADE, T. M. C.; DIAS, H. C. T. Water table monitoring in a mined riparian zone. Ambi-Agua, Taubaté, v. 5, n. 1, p. 29-42, 2010. (doi:10.4136/ambi-agua.117)
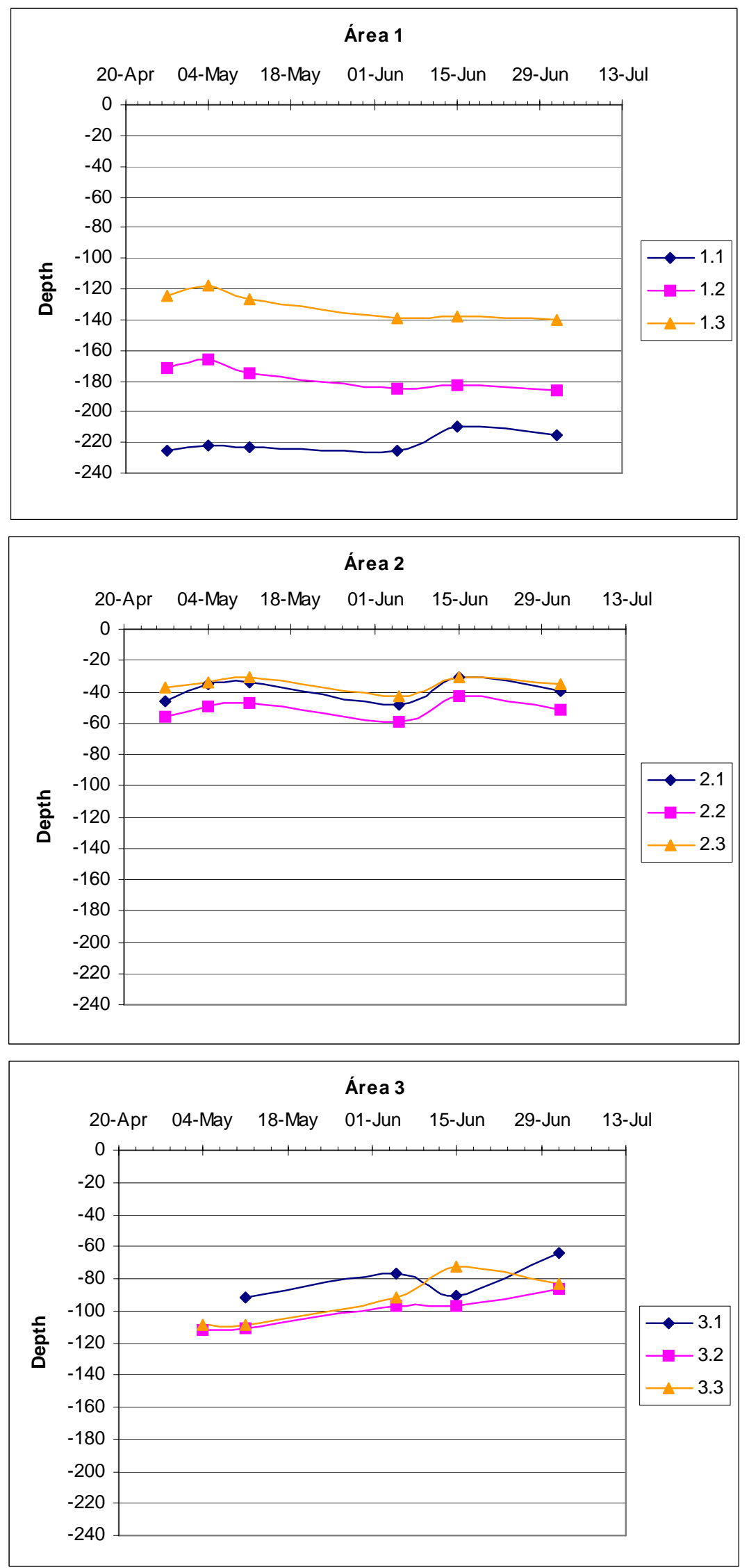

Figure 7. Groundwater level variation over time in the three observed areas, in centimeters, following a transect from the Gualaxo do Norte River bank. Minas Gerais, Brazil, Apr/Jul, 2007. 
A comparison of data variation over time and position on the plot from areas 1 and 2 indicated that the two areas have distinct hydrologic behaviors. Area 1 is closer to the classical hydrologic models like the one observed by Marinho and Castro (2003) of steep and usually unsaturated areas with infiltration excess runoff production (Horton, 1933; 1940) and area 2 is more likeable to fit the Variable Source Area model (Hewlett and Hibbert, 1967; Dunne, 1970; Dunne and Black, 1970; Hewlett and Nutter, 1970; Dunne et al., 1975), generally flatter, with shallow water table, where saturation is likely to occur and generate runoff.

The results of area 3 were markedly different from the other two. Between May $11^{\text {th }}$ and June $5^{\text {th }}$, groundwater levels of the previous areas were reduced, while it rose at area 3 . Furthermore, between $5^{\text {th }}$ and $15^{\text {th }}$ of June the level in well 3.1 decreased by $14.5 \mathrm{~cm}$, no changes were detected on 3.2 and an increase of $19.5 \mathrm{~cm}$ was reported in well 3.3. The following measurement, at July $2^{\text {nd }}$, showed the inverse, with an elevation of water level in the well 3.1 and a reduction in the 3.3. An important consideration about area 3 is that the soil was recomposed more recently and gold extraction was still going on about two weeks prior to the measurements. Hence it is possible that groundwater had been going through a period of adaptations to the new conditions and is still unstable. The crossing of the 3.1 and 3.3 well curves in the chart of Figure 6 can be a result of that. Another difference between area 3 and the other ones is that there was a raise of the water table in the whole period, unlike the drop observed at areas 1 and 2. This is an evidence that groundwater at area 3 was not yet in its steady state by the time of the measurements. The area was a big mining hole where sediment from the river bed was dragged out and after the replacement of the soil, water table may be rising through the soil pores by capillarity. Since the soil was placed without following any specific criteria, hydraulic conductivity may be varying within the plot, therefore causing variability between groundwater levels.

Although soil mechanical resistance was different among the wells in area 3 , it is premature to say if the magnitude of this difference is enough to generate disparities of porosity and hydraulic conductivity. Resistance in the research site (Table 4) ranged from 0,023 to 0,042 and was markedly lower than findings on natural soils or those that were not fully removed and replaced. Cunha et al. (2002) founded values between 0,260 and 1,148 $\mathrm{MPa}$, while Klein et al. (1998) affirm that the limiting resistance of most crops is around 2 $\mathrm{MPa}$. The research site is surrounded by Tropical semideciduous forest and Eucalyptus plantations, where penetrometer resistance can be around 1.7 MPa (Martinelli et. al., 2002) and 1.1 MPa (Lopes et al., 2006) respectively. The low mechanical resistance of the soil at all plots emphasizes the need of reinforcement improvements on the well drilling tool and that it is to be used only in low resistance soils.

Table 4. Mechanical resistance of the soil in the measurement plots installed at Galaxo do Norte River Watershed, Minas Gerais, Brazil, 2007.

\begin{tabular}{lccccc}
\hline Piezometer & $\mathbf{c m}$ & $\mathbf{K g}$ & $\mathbf{k g} / \mathbf{m} \mathbf{2}$ & $\mathbf{M P a}$ & $\mathbf{M P a} / \mathbf{c m}$ \\
\hline $\mathbf{1 . 1}$ & 17,38 & 294,0 & $415.959,25$ & 0,04241 & 0,0245 \\
$\mathbf{1 . 2}$ & 19,00 & 216,2 & $305.885,68$ & 0,03119 & 0,0183 \\
$\mathbf{1 . 3}$ & 13,25 & 202,2 & $286.078,10$ & 0,02917 & 0,0220 \\
Avg area 1 & $\mathbf{1 6 , 5 4}$ & $\mathbf{2 3 7 , 4 7}$ & $\mathbf{3 3 5 . 9 7 4 , 3 4}$ & $\mathbf{0 , 0 3 4 2 6}$ & $\mathbf{0 , 0 2 1 6}$ \\
\hline $\mathbf{2 . 1}$ & 19,10 & 200,6 & $283.814,37$ & 0,02894 & 0,0153 \\
$\mathbf{2 . 2}$ & 23,20 & 192,8 & $272.778,72$ & 0,02781 & 0,0123 \\
$\mathbf{2 . 3}$ & 26,86 & 259,2 & $366.723,26$ & 0,03739 & 0,0139 \\
Avg Área 2 & $\mathbf{2 3 , 0 5}$ & $\mathbf{2 1 7 , 5 3}$ & $\mathbf{3 0 7 . 7 7 2 , 1 2}$ & $\mathbf{0 , 0 3 1 3 8}$ & $\mathbf{0 , 0 1 3 8}$ \\
\hline $\mathbf{3 . 1}$ & 11,80 & 202,8 & $286.927,00$ & 0,02926 & 0,0253 \\
$\mathbf{3 . 2}$ & 18,70 & 196,6 & $278.155,07$ & 0,02836 & 0,0152 \\
$\mathbf{3 . 3}$ & 18,70 & 162,2 & $229.485,00$ & 0,02340 & 0,0125 \\
Avg Área 3 & $\mathbf{1 6 , 4 0}$ & $\mathbf{1 8 7 , 2 0}$ & $\mathbf{2 6 4 . 8 5 5 , 6 9}$ & $\mathbf{0 , 0 2 7 0 1}$ & $\mathbf{0 , 0 1 7 7}$ \\
\hline
\end{tabular}


The sediment reposition after mining was done in a way that different layers were formed. Figure 8 shows a soil profile at area 1 and the effect of the well drilling upon it. The upper $50 \mathrm{~cm}$ presented several distinct layers organized in an heterogeneous pattern, while after that it became more homogeneous. Piezometers perforation had altered the layer's structure, as it pushed particles downward at the well, forming a funnel shape design. This new configuration of the layers, however, may contribute to an overestimation of water table data by promoting a higher infiltration rate just around the well and also orienting the water to a less permeable stratum. Furthermore, overestimation might be increased by water flow through the external surface of the PVC cover.

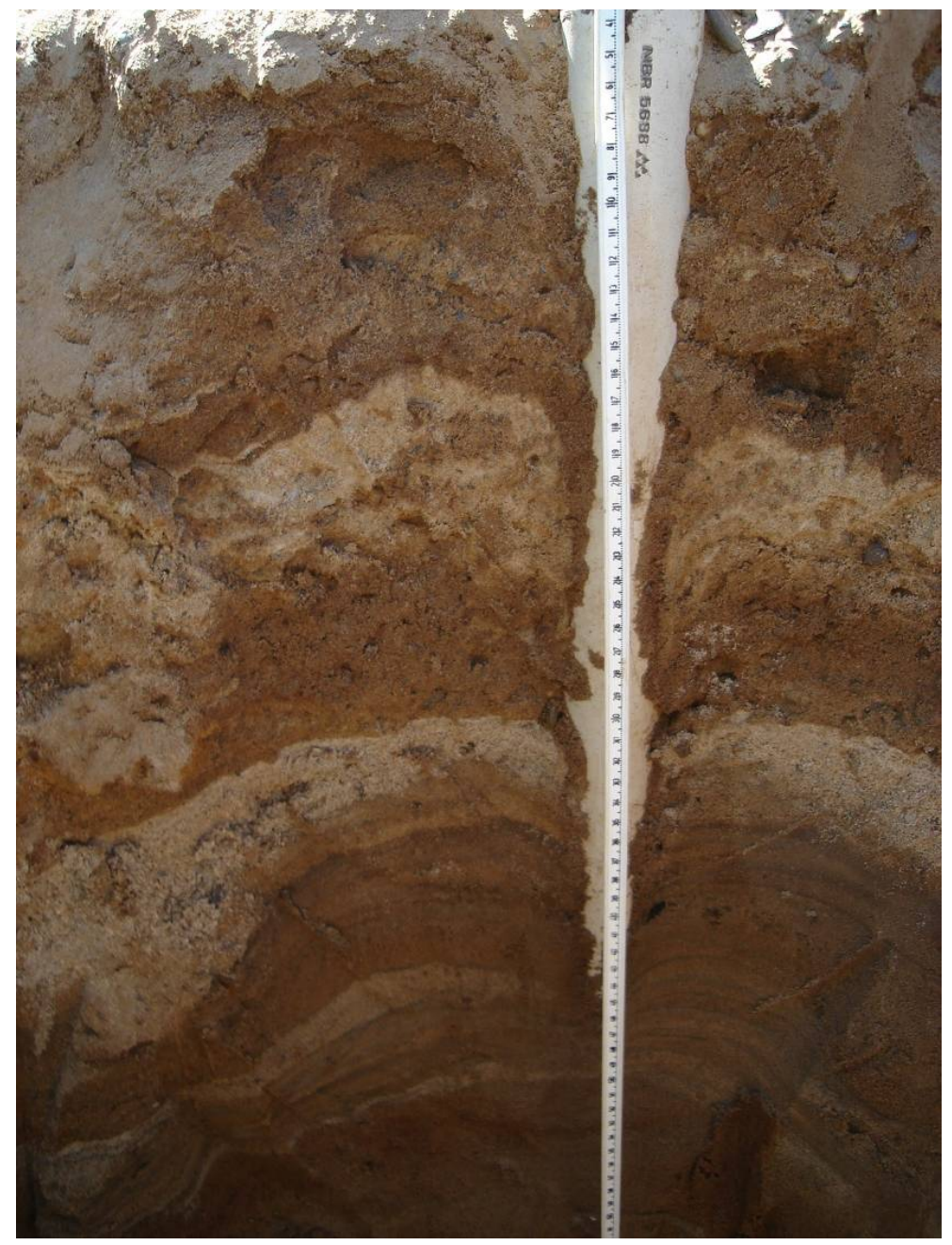

Figure 8. Soil profile from 0 to $60 \mathrm{~cm}$ at the location of piezometer 1.1 at the Gualaxo do Norte River Watershed, Minas Gerais, Brazil, 2007.

\section{CONCLUSION}

The results have showed that the manual well drilling tool is a viable alternative to install piezometers up to 3 meters deep in low resistance soils.

The water table level reflects physiographic characteristics of the landscape and might be a good reference for bank leveling where upper layers of the soil where removed. This has to be done following consistent hydrologic models of similar watersheds.

The reconstitution of upper layers of the soil must seek the maintenance of previous substrates infiltration capacity in order to conserve original subsuperficial flow dynamics. 


\section{REFERENCES}

BOHN, C. C. Guide for fabricating and installing shallow ground water observation wells. Ogden: USDA Forest Service, Rocky Mountain Research Station, 2001, 5 p. (Research note RMRS-RN 9)

CUNHA, J. P. A. R. da; VIEIRA, L. B.; MAGALHÃES, A. C. Resistência mecânica do solo à penetração sob diferentes densidades e teores de água. Engenharia na Agricultura, v. 10, n. 1/4, jan./dez. 2002. Disponível em: <http://www.ufv.br/dea/reveng/arquivos/ vol10/v10n1-4p01-07.pdf>. Acesso em: 07 jul. 2007.

DUNNE, T. Runoff production in humid areas. Washington: U.S. Department of Agriculture, 1970. 108 p. (Publication ARS-41-160)

DUNNE, T.; BLACK, R. D. Partial area contributions to storm runoff in a small New England watershed. Water Resource, v. 6, p. 1296-1311, 1970.

DUNNE, T.; MOORE, T. R.; TAYLOR, C. H. Recognition and prediction of runoffproducing zones in humid regions. Hydrological Sciences Bulletin, v. 20, n. 3, p. 305$327,1975$.

DUNNE, T.; LEOPOLD, L. B. Water in environmental planning. San Francisco: W. H. Freeman and Company, 1978. $817 \mathrm{p}$.

FERREIRA, J. S.; LIMA, H. M.; PINTO, D. S. S. Gestão da produção e gerenciamento ambiental integrado para extração de ouro por draga no rio Gualaxo do Norte, Mariana. In: CONGRESSO BRASILEIRO DE MINA A CÉU ABERTO, 4., 2006, Belo Horizonte. Anais... Belo Horizonte: DNPM, 2006. 1 CD-ROM.

HORTON, R. E. The role of infiltration in the hydrologic cycle. Transactions American Geophysical Union. v. 14, p. 446-460, 1933.

HORTON, R. E. An approach toward a physical interpretation of infiltration capacity. Soil Science Society of America Proceedings, v. 4, p. 399-417, 1940.

HEWLETT, J. D.; HIBBERT, A. R. Factors affecting the response of small watersheds to precipitation in humid regions. In: SOPPER, W. E.; LULL, H. W. Forest Hydrology. Oxford: Pergamon Press, 1967. p. 275-290.

HEWLETT, J. D.; NUTTER, W. L. The varying source area of streamflow from upland basins. In: SYMPOSIUM ON INTERDISCIPLINARY ASPECTS OF WATERSHED MANAGEMENT, 1970, Bozeman. Proceedings... New York: ASCE, 1970. p. 65-83

KLEIN, V. A.; LIBARDI, P. L.; SILVA, A. P. Resistência mecânica do solo à penetração sob diferentes condições de densidade e teor de água. Engenharia Agrícola, Jaboticabal, v. 18, n.2, p.45-54, dez. 1998. Disponível em: <http://www.sbea.org.br/rea/numero10/ trab5.htm>. Acesso em: 07 jul. 2007.

LOPES, S. E.; FERNANDES, H. C.; VIEIRA, L. B.; MACHADO, C. C.; RINALDI, P. C. N. Evaluation of compaction of a forest soil subjected to skidder traffic. Revista Árvore, Viçosa- MG,v. 30, n. 2, May/Jun. 2006. Disponível em: <http://www.scielo.br/scielo. php?script $=$ sci_arttext\&pid $=\mathrm{S} 0100-67622006000300007 \& \operatorname{lng}=\mathrm{en} \& \mathrm{nrm}=\mathrm{iso}>$. Acesso: 9 oct. 2007. 
MARINHO, G. V.; CASTRO, S. S. Caracterização físico-hídrica e de suscetibilidade a voçorocamento dos solos da subbacia do córrego queixada, na alta bacia do rio Araguaia-GO. In: SIMPÓSIO BRASILEIRO DE GEOGRAFIA FÍSICA APLICADA, 10., 2003, Rio de Janeiro. Anais... Rio de Janeiro: UERJ, 2003. Disponível em: $<$ http://geografia.igeo.uerj.br/xsbgfa/cdrom/eixo3/3.4/310/310.htm>. Acesso em: 01 jul. 2007.

MARTINELLI, B. M.; DIAS, H. C T.; PAIVA, H. N. de; SALIM NETO, S. C. Resistência mecânica à penetração em solos com diferentes usos. In: REUNIÃO BRASILEIRA DE MANEJO E CONSERVAÇÃO DO SOLO E DA ÁGUA, 14., Cuiabá, 2002. Resumos... Cuiabá: UFMT, 2002. 1 CD-ROM.

TAYLOR, C. J.; ALLEY, M. W. Ground-water-level monitoring and the importance of longterm water-level data. U.S. Geological Survey Circular, Denver, v. 1217, p. 2-6, 2001. Disponível em: <http://pubs.usgs.gov/circ/circ1217/html/pdf.html>. Acesso em: 09 jul. 2007. 